\title{
The Byronic Vampire in Ann Rice's Gothic World
}

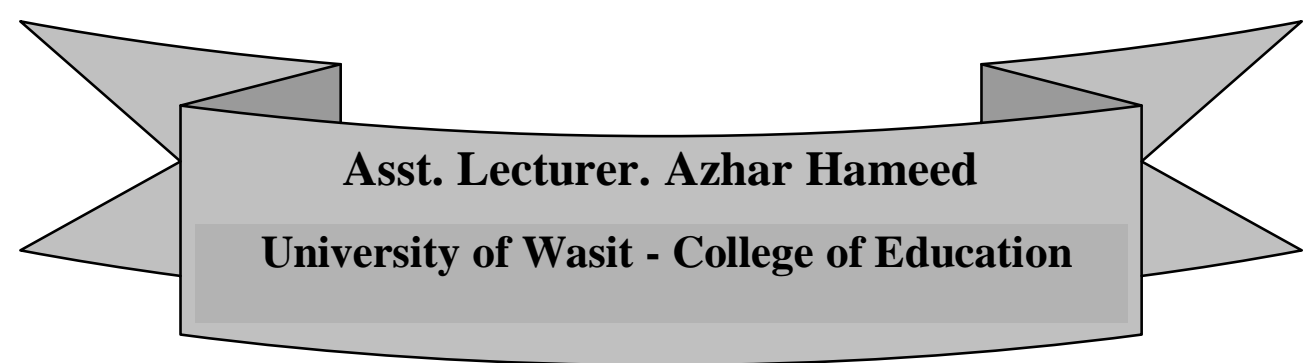

\section{Abstract:}

In this paper my objective is to trace a unique form of modern vampirism represented in Ann Rice's( 1941- ) The Vampire Chronicles . Ann Rice is bringing together this mythological figure with the already established Byronic heroes. I will determine whether or not Lestat in Ann Rice's gothic novels is the culmination of the current understanding of the a Byronic hero.The paper closely examines the character of Lestat in Rice's The Vampire Chronicles to show how Rice manages to attract the reader's attention through not only her storytelling gift, but also through her intellectual, gloomy, erotic and fascinating characters who are somewhat wicked and depraved and but in strangely appealing and attractive way.

يبحث هذا البحث شخصية مصاص الدماء فى قصص ان رايس وعلاقتها بالابطال البايرونية .كذلك يدرس البحث كيفية ربط الخيال بالتاريخ وهل نجدت رايس في هذه المهمة .ولتحليل شخصية

مصاص الدماء سوف يحلل البحث شخصية ليستات فى مجموعة قصص مصاص الاماء ل ان رايس ليبين كيف ان الكاتبة قدمت شخصيات مخيفة ومرعبة بطريقة رائعة ومثيرة. 
The plots in many of Ann Rice's( 1941- ) novels mirror a series of tragedies which occurred during her life. Her mother drank herself to death when she was only fourteen. Her attraction to the mystical, her life in New Orleans, and death of her daughter at the age of five all encouraged Anne Rice to write Interview With The Vampire(1976). She demonstrate powerful and mysterious emotions in her writings. Her debut novel, Interview with The Vampire (1976), attracted a large popular audience and recognized her as a primary modern author of horror fiction. In a way, Rice's horror novels have served as a therapeutic exit for her pain. She says " The Vampire is a powerful metaphor, for the outcast inside us for the monster in all of us, for the predator in all of us." ${ }^{1}$ Ramsland suggests that writing through immortal characters gave Rice a safe place to contemplate death, and in her writings it was evident that the destructive nature of the vampire was what alcohol had done to her mother Katherine, "what leukemia had done to Michele ${ }^{\prime 2}$ and what Michele's death had done to Rice. Rice was torn between painful remembering and the longing to forget, she found a way to combine both in the "flexibility and tolerance of fiction" ${ }^{3}$.In her first vampire novel she would 'resurrect Michele' and in her later novels she would do the same for her mother . Ramsland states, "Rice wanted to look at the vampire as a tragic figure, a human who had made the mistake of choosing such an existence to his deepest regret"4 $^{\prime 4}$

Rice's Chronicle to Vampire(1976) was initially attributed to Byron; because Rice borrowed some plot elements from an abandoned narrative fragment by Byron. Lord Byron is the creator and inspiration of the Byronic hero. Emerging from abusive childhood his adult years

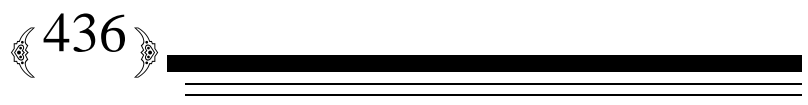


were marked by numerous personal scandals, including failed marriages , accumulating debts, and many failed love affairs . This makes Lord Byron praise and glorify heroes who could overcome hardships. One of the women he had a relationship with described him as "mad, bad and dangerous to know" 5 .This becomes one of the major features of the Byronic hero. Despite the public detestation of his lifestyle , Byron remains indifferent. This aspect of Byron's personality is included in the description of the Byronic Hero . The Byronic hero has been a relevant, admired and compelling character in both classical literature and popular culture. Lestat in Ann Rice's gothic novels is incontestable in his categorization of the Byronic hero .He has inescapable affinity for danger, cursed and damned fate, and a bitter outlook on the world he has been forcefully thrust into and can never break from , qualities often associated with the traditional Byronic hero $^{6}$. Through Rice's characterization, the standards of a Byronic hero is set.

Martin J. Wood mentions That the vampires in Rice's novels bridge the $19^{\text {th }}$ and the $20^{\text {th }}$ centuries when Rice connected them to the Byronic figure .For Rice The Romantic Period has never ended. Therefore; we still find the Byron's heroes in her stories. The reemergence of the Byronic hero into mainstream fiction and film is of broad historical and sociological interest. ${ }^{7}$ Wood adds that Rice searches for an ambitious, antisocial, arrogant, and aggressively individualistic mode of hero from his inception in Byron's Manfred, Childe Harold, and Cain, through his incarnations as the protagonists of Westerns, action films, space odysseys, vampire novels, neo-Gothic comics, and sci-fi television. ${ }^{8}$ 
Rice's vampire is a creature in strictly human form, with no huge teeth in the front of its mouth ,and no bald head or pointed ears, a creature with human emotions and human drives, a creature that can pass freely in the world of men and need not fear detection in the enlightened society through which he stalks. This aristocratic figure who mingles in high society, delighting and thrilling all with his strange mannerisms and moods, is a far cry from the lonely beast rampaging through the forest tearing out the throat of any passing creature in order to carry on his vile existence. Here we have a creature altogether more terrifying in its sheer plausibility: it looks human, acts almost human, talks like a human, and moves among the highest echelons of society. A couple of things Rice does make her vampire world so fascinating. The vampires act as their own little microsociety with rules and taboos that are well thought out and extremely interesting. ${ }^{9}$

As Williamson points out, through the twentieth century the image of the vampire increasingly becomes compassionate. This is one of the most significant shifts in the vampire fiction and represents to Rice "a change in cultural attitudes toward the outsider, the alien and the other." ${ }^{10}$ Jules Zanger remarks that with each variation of the vampire the new vampire becomes more affectionate and more accepted. Never before had a text been so widely available which dealt with such a disturbing yet fascinating matter. The importance of the vampire's physical attractiveness is a strong one, and one to which the reader's attention is constantly drawn in seemingly paradoxical references. $^{11}$ 
This new and developed vampire no longer instigates only fear and dread in the reader but also draws out other emotional responses. Williamson explains "it is no longer predominantly a figure of fear in Western popular culture, but a figure of sympathy"12. Lestat and other vampires are arguably the modern day understanding of what a Byronic hero could be. Through the mid- to late twentieth century the vampire tradition takes an important rotation in presenting the vampire characters as story-tellers, presenting the readers, according to Williamson, "otherness from the inside." ${ }^{13}$ Rice's character Lestat along with Louis and other vampires in her Vampire Chronicles can be seen as modern Byronic heroes with Lestat being the more classic example. Moreover, the location of the vampire has changed. They no longer, as they did before Rice's fiction, reside in distant and secluded places, for example, Lestat, Louis and other vampires in the Rice's Chronicles live in "comfortable, well-furnished places generously appointed with art and cultural artifacts gathered through the centuries." 14 The vampire in the $20^{\text {th }}$ century might live next door.

Stein quotes Rice : "I've always been fascinated by the vampire, the elegant yet evil Byronic figure" ${ }^{15}$.The eternal boredom and frustration attract and repel the reader and cause the fascination of both the modern reader and the 18th century reader. Rice's own references to Byron suggest that she deliberately casts Lestat into a Byronic mode, and as Kathryn McGinley points out, "For Byronic heroes [... ] particularly the Ricean version, immortality can be simultaneously desirable and intolerable".. ${ }^{16}$ 
A Byronic hero is someone much like the Romantic hero who rejects and is rejected by the society. He is steeped with darkened, destructive, dangerous traits. A Byronic hero can be considered a rebel. He does not possess "heroic virtue" in the usual sense; instead, he has many dark qualities. With regard to his intellectual capacity, selfrespect, and hypersensitivity, the Byronic hero is "larger than life," and "with the loss of his titanic passions, his pride, and his certainty of selfidentity, he loses also his status as [a traditional] hero. ${ }^{17} \mathrm{He}$ is usually isolated from society as a wanderer or is in exile of some kind. It does not matter whether this social separation is imposed upon him by some external force or is self-impose. This feature could be found in the character of Lestat. Williamson observes that the Lestat is presented as a rebellious outsider ${ }^{18}$.He is the rebel, defining his own moral code, and rebelling against all authority, both human and vampiric. Lestat sees himself "as a hungry, vicious creature, who did a very good job of existing without reasons, a powerful vampire who always took exactly what he wanted, no matter who said what"19

He seems reminiscent of Byron's Childe Harold and Cain when he says, "I'd been born restless ,dreamer, angry and a complainer." ${ }^{20}$ The novelist herself explains:

I've always been fascinated by the vampire, the elegant yet evil Byronic figure. It's easy to say it's a metaphor for the outsider, the predator, anyone who feels freakish or monstrous or out of step but appears normal. ${ }^{21}$ 
His reckless disregard for authority has led him to his popularity in text , films , and television .He chooses to execute his own sense of judgment when he finds the right way is not working ${ }^{22}$. Lestat is not only an outlaw to human society by virtue of being a vampire, but he is also a rebel among vampires, disregarding their rules and conventions. He conceives "an unprecedented rebellion, a great and horrific challenge to my kind all over the world" ${ }^{\prime 23}$. Lestat defiantly announces: "Old rules didn't matter to me now, either. I wanted to break every one of them." ${ }^{24}$ Louis also embraces his own form of rebellion a against the vampire civilization of which he unwillingly becomes part .He takes it upon himself to protect Claudia from Lestat. He is sorry that he can't do anything to restrain Lestat from taking human lives in their land.

The Byronic hero as described by McGinley is "a charming, seductive, aristocratic character with a diabolical narcissism and desire to control" ${ }^{\prime 25}$.Lestat is described as a gracious outlaw and an aristocratic rebel who craves independence and power, breaking all the rules as in making a child vampire, revealing himself and the other vampires to mortals, and trying to become mortal again .As he was made into a vampire against his will, he is resolute in making the most of it and "finds vampirism the greatest adventure of his existence" ${ }^{26}$. Rice says:

My hero, the Vampire Lestat, the genderless giant who lived in me, was always the voice of my soul in this novel , and it is no accident that he begins it with a cry of the heart, 'I want to be a saint, I want to save the souls of millions!' [But]by the end of the novel, confessing his failure ever to be anything but a rambunctious reprobate and 
Byronic sinner. He...resigned as the hero of the books which had given him life...This character who had been my dark search engine for twenty-seven years would never speak in the old framework again. ${ }^{27}$

McGinley describes Lestat saying: "In Lestat, there is a splendidly aristocratic figure who has been corrupted from good to evil, largely by events beyond his own control"28 . Though deserving of sympathy, Lestat is clearly undeserving of a happy ending, while louse's crime are tame enough to be forgiven. Lestat is a natural leader of men, though basically an independent figure, at odds with others, someone with an unshakable pride, ungovernable passions and a ravaged heart. McGinley notes as well that the Byronic hero is also marked by guilt, and Louis certainly fills that description. He feels immensely guilty over the fact that he has to kill to sustain himself and he tries very hard to hold on to his human sense .Louis is the most human of Rice's vampires. ${ }^{29}$ Even Lestat is racked with guilt over his friend's suicide . Some of their attitudes and actions may be considered immoral, and their bad actions may be as numerous as those which are heroic, but never are they evil for evil's sake ${ }^{30}$.

As Lestat points out:

what is the problem? The fittest always survives, and whoever is lower down the food-chain will be eaten. Humans eat animals, and vampires eat humans - it's all natural. But nonetheless, are there moral limits? Even if you have to kill a human, is there a more moral way to do it? ${ }^{31}$ 
But it is deferent for Louis who exclaims, "Monstrous, ${ }^{\text {"32 }}$ when he watches a group of vampires murder a defenseless girl. For Louis, survival might not require the forgetting of moral consciousness .Though Lestat might be completely different from Louis, but their powerful relationship make them strangely similar, and it becomes clear that Lestat's characterization fits perfectly with the evolution of vampires in popular culture and with the evolution of the Byronic hero. Louis 's gentle nature might be unfit when compared to more classic Byronic heroes, simply put, the Byronic hero of today is no longer dark. $^{33}$

McGinley argues that because the vampires in Rice's fiction hold such strong human emotions, including love and guilt. They go a step beyond Dracula. Another important aspect McGinley mentions is Rice's vampire characters' capacity to love. Lestat and Louis and the other vampires in Rice's fiction all seem to love each other one-way or the other, "as they need companionship to endure their immortality." 34

To McGinley Lestat and Louis each displays different sides of the Byronic hero making them polar opposites. They are two opposites: the 'Hero of Sensibility' and the 'noble outlaw' ${ }^{35}$. He places Louis in the category of the Hero of Sensibility, stating "he has humanitarian sympathies, and his love is as tender as it is passionate ${ }^{\prime 36}$, and Lestat being the noble outlaw. In conclusion McGinley notes that the final parallel between Byron and vampires is the imagery of eternity and immortality observing that one of the strongest fascinations with vampires for modern readers is the idea of immortality, because of humanities natural fear of death and for that reason vampires are frightening, "for they may bring death faster than we expect" ${ }^{37}$. 
However, to vampires and especially to the Ricean vampires as McGinley remarks, immortality can be both desirable and intolerable for, "eternity can seem an overwhelmingly long time." ${ }^{38}$ Louis, who began as a depressive wanting to die, thinks of eternity as an extended curse; Lestat, who seems to live every second as it comes, barely even considers the future three minutes hence. Told from Louis' viewpoint as he struggles to find some meaning in a life he knows will never end . Even though Louis is clearly dissatisfied with life, he never attempts to end it. By creating vampires more human than Dracula, "capable of love and suffering under the weight of a guilty conscience, which Dracula did not posses", ${ }^{39}$ McGinley states that Rice has further modernized the vampire while at the same time "returning it to its Byronic roots" ${ }^{\prime 40}$.. As Zinger notes:

"Rice's vampires are loquacious philosophers who spend much of eternity debating the nature of good and evil. Trapped in immortality, they suffer human regret. They are lonely, prisoners of circumstance, compulsive sinners, full of self-loathing and doubt. They are, in short, Everyman Eternal." ${ }^{41}$ 


\section{Conclusion}

After extensive research I attempt to say that this paper is not meant to challenge the traditional Byronic hero, but to expand on him , accepting that each new generation adds their own interpretation to Byronic hero, and that although some of his tendencies might be changed or altered, at the core, he is still Lord Byron's Byronic hero. Because there is no definite Byronic hero with completely definitive features, this helps to the emergence of a modernized version of him. Rice's vampire are often associated with Byronic heroes who continue to fascinate and charm readers and viewers alike.

Rice's vampires are typically dispossessed or alienated individuals who wrestle with existential questions of morality and death . Rice"s immortals are beautiful, do not live in graves, and can see their reflections in mirrors. They have more freedom and seem less like monsters Rices stories are much more modern, not only in setting and the characters abilities but also in the way the vampires act and think :

\section{$\underline{\text { Notes }}$}

${ }^{1}$ Mary Pharr, "Vampiric Appetite in I Am Legend, 'Salem's Lot, and The Hunger." The Blood is the Life: Vampires in Literature. Ed. Mary Pharr Leonard G. Heldreth( Bowling Green: Bowling Green State University Popular Press, 1999),p. 67.

2 Terri R Liberman, "Eroticism as Moral Fulcrum in Rice's Vampire Chronicles." The Gothic World of Anne Rice (Bowling Green:Bowling Green State University Popular Press, 1996),p.45 
${ }^{3}$ Candace R. "Blood Relations: The Gothic Perversion of the Nuclear Family in Charismatic Personalities: Exploring the Anne Rice Phenomenon." The Gothic World of Anne Rice.( Bowling Green: Bowling Green State University Popular Press, 1996),p.98

${ }^{4}$ Milly Williamson, The Lure of the Vampire: Gender, Fiction and Fandom from Bram Stoker to Buffy( London: Wallflower Press, 2005) ${ }^{5}$ Jules Zanger, "Metaphor into Metonymy: The Vampire Next Door." Blood Read: The Vampire as Metaphor in Contemporary Culture. Ed. Joan Gordon and Veronica (Bowling Green: Bowling Green State University Popular Press, 1999),p. 23.

${ }^{6}$ Milly Williamson,65

${ }^{7}$ Ibid,p.56

${ }^{8}$ Beth E Mcdonald, The Vampire as Numinous Experience: Spiritual Journeys with the Undead in British and American Literature. Jefferson, NC: McFarland, 2004.

9ibid

${ }^{10}$ Martin J Wood, "New Life for an Old Tradition: Anne Rice and Vampire Literature."The Blood Is The Life: Vampires in Literature. Ed. Leonard G. Heldreth and Mary Pharr. Bowling Green: Bowling Green State University Popular Press, 1999.

${ }^{11}$ ibid.p.34

${ }^{12}$ ibid.p.67

${ }^{13}$ Margaret L Carter. "The Vampire as Alien in Contemporary Fiction." Blood Read: The Vampire as Metaphor in Contemporary Culture.( Bowling Green: Bowling Green State University Popular Press, 1988),p.99 
${ }^{14}$ Mcdonald,p.96

${ }^{15}$ ibid.p.12

${ }^{16}$ ibid,p.25

${ }^{17}$ williamson,p.19

${ }^{18}$ Kathryn McGinley, "Development of the Byronic Vampire: Byron, Stoker, Rice." The Gothic World of Anne Rice. Ed. Ray B. Browne Gary Hoppenstand( Bowling Green: Bowling Green University Popular Press, 1996),p.56

${ }^{19}$ ibid.p.57

${ }^{20}$ ibid.p.76

${ }^{21}$ Ann rice

${ }^{22}$ Ann rice

${ }^{23}$ Terri R Liberman, "Eroticism as Moral Fulcrum in Rice's Vampire Chronicles." TheGothic World of Anne Rice(Bowling Green:Bowling Green State University Popular Press, 1996.),p.66

${ }^{24}$ Ann rice

${ }^{25}$ Ann rice

${ }^{26}$ Mary Pharr, "Vampiric Appetite in I Am Legend, 'Salem's Lot, and The Hunger." The Blood is the Life: Vampires in Literature. Ed. Mary Pharr Leonard G. Heldreth( Bowling Green: Bowling Green State University Popular Press, 1999),p.93

${ }^{27}$ ibid,p.44

${ }^{28}$ McGinley,p.77

${ }^{29}$ ibid,p.48

${ }^{30}$ ibid,p.65

${ }^{31}$ Ann rice

${ }^{32}$ ibid,p.78 
${ }^{33}$ McGinley,p.99

${ }^{34}$ ibid,p.98

${ }^{35}$ ibid,p.94

${ }^{36}$ ibid,p.54

${ }^{37}$ ibid,p.47

38 Jules Zanger, "Metaphor into Metonymy: The Vampire Next Door."

Blood Read: The Vampire as Metaphor in Contemporary Culture. Ed. Joan Gordon and Veronica

${ }^{39}$ McGinley,p.69

${ }^{40}$ Jules Zanger,p.36

${ }^{41}$ Nina Auerbach, Our Vampires, Ourselves( Chicago: Chicago University Press, 1995),p.29

${ }^{42}$ Judith Butler, Gender Trouble. Feminism and the Subversion of Identity( New York \& London: Routledge, 1990),p.87

Bibliography

Rice, Anne. Interview with the Vampire : a novel. New York: Knopf, 1976.

The Vampire Lestat. New York: Ballantine Books, 1986.

Auerbach, Nina. Our Vampires, Ourselves. Chicago: Chicago

University Press, 1995.

Butler, Judith. Gender Trouble. Feminism and the Subversion of

Identity. New York \& London: Routledge, 1990.

Candace R. "Blood Relations: The Gothic Perversion of the Nuclear

Family in Charismatic Personalities: Exploring the Anne Rice 
Phenomenon." The Gothic World of Anne Rice. Bowling Green: Bowling Green State University Popular Press, 1996. www.ivsl.org

Carter, Margaret L. "The Vampire as Alien in Contemporary Fiction." Blood Read: The Vampire as Metaphor in Contemporary Culture. Bowling Green: Bowling Green State University Popular Press, 1988 Liberman, Terri R. "Eroticism as Moral Fulcrum in Rice's Vampire Chronicles." TheGothic World of Anne Rice.Bowling Green:Bowling Green State University Popular Press, 1996.

McGinley, Kathryn. "Development of the Byronic Vampire: Byron, Stoker, Rice." The Gothic World of Anne Rice. Ed. Ray B. Browne Gary Hoppenstand. Bowling Green: Bowling Green University Popular Press, 1996.

Mcdonald, Beth E. The Vampire as Numinous Experience: Spiritual Journeys with the Undead in British and American Literature. Jefferson, NC: McFarland, 2004. www.ivsl.org

Pharr, Mary. "Vampiric Appetite in I Am Legend, 'Salem's Lot, and The Hunger." The Blood is the Life: Vampires in Literature. Ed. Mary Pharr Leonard G. Heldreth. Bowling Green: Bowling Green State University Popular Press, 1999

Williamson, Milly. The Lure of the Vampire: Gender, Fiction and Fandom from Bram Stoker to Buffy. London: Wallflower Press, 2005. www.ivsl.org

Wood, Martin J. "New Life for an Old Tradition: Anne Rice and Vampire Literature."The Blood Is The Life: Vampires in Literature. Ed. 
Leonard G. Heldreth and Mary Pharr. Bowling Green: Bowling Green State University Popular Press, 1999.

Zanger, Jules. "Metaphor into Metonymy: The Vampire Next Door."

Blood Read: The Vampire as Metaphor in Contemporary Culture. Ed. Joan Gordon and Veronica. Bowling Green: Bowling Green State University Popular Press, 1997. 